\title{
THE VALUE AND TOPICALITY OF FEEDBACK IN IMPROVING THE LEARNING PROCESS
}

\author{
Pāvels Jurs \\ University of Liepāja, Latvia \\ Elita Špehte \\ University of Liepāja, Latvia
}

\begin{abstract}
Feedback delivery is an integral part of the learning process, which provides an effective teaching and learning process. Although students are primarily targeted to get a mark, there are a number of strategies that can be used to maximise students' involvement in the learning process, including providing effective feedback. Purposeful use of feedback through the pedagogical process contributes to a more active involvement of students by developing metacognitive skills (Nicol \& Draper, 2008). It is important to encourage students, in the learning process and outside it, to ensure reflection on feedback comments and to give preliminary assessment (Taras, 2003). The aim of the article is to update the importance of feedback in the pedagogical process by identifying theoretical regularity in the interpretation of the concept of feedback, as well as undertaking empirical research to clarify students' views on feedback and the effectiveness of its application in the learning process.
\end{abstract}

Keywords: feedback, learning process, student, teacher.

\section{Introduction}

In the 21st century, employers want to see in their businesses employees who are able to recognize opportunities, identify problems, choose solutions that are unprecedented, create innovative products. Social skills, the ability to critically evaluate information, use knowledge, desire and lifelong learning are particularly demanded. A knowledge-based society is being developed worldwide and a new economic model based on knowledge and known as a knowledge-based economy is being implemented (UNESCO, 2005). The Lisbon strategy underlines that education and research have the greatest impact on growth and employment (The European Council, 2000). In order to achieve the educational goal, the learning process should provide feedback that supports and regulates learning. Feedback is needed for both students and teachers to improve the work of both students and teachers. 
The object of the present study is feedback provided to students in secondary school, classes 6-8. The research is aimed to analyse feedback and its use in school from the theoretical and practical perspectives. Research goals include:

1) defining the role of feedback provided to students in school at primary level;

2) discussing features of effective feedback provided to students. The purpose of the study was to explore student perceptions of feedback. Participants consisted of 69 students from classes 6-8. The research methods used in the study include:

1) literature analysis which was used to establish the role of feedback and different approaches to it, as well as its use at school;

2) empirical - data extraction method (survey), data processing and analysis were used to investigate relationships between feedback, teaching, assessment and students` learning in school.

\section{Analysis of the concept of feedback and the importance of its effectiveness}

Feedback is one of the preconditions for successful cooperation in the pedagogical environment, and it is an important part of the formative evaluation process. The main question for feedback is how to improve student learning trough the information the teacher provides, which allows students both to reactivate and consolidate prior knowledge as well as focus in important aspects what they are learning (Boud \& Molloy, 2013). Systematic evaluation provides answers to teachers and students on questions: What to learn? What is achieved and what is not? What to do next? (Thompson, 2007; Timperley, 2007; Draper, 2008). Education researchers A. Kluger and A. DeNisi, it should be noted that feedback is defined as ,actions taken by an external agent to provide information regarding some aspects of one's task performance” (Kluger \& DeNisi, 1996), thereby, by highlighting the importance of feedback in the evaluation process, most of the performance relates to learning, achievements or attitudes about what is being taught. Feedback is made up of constructive criticism and advice, it can also be manifested as behaviour. Feedback is thought-out and targeted information provided by the teacher to the student about his or her own actions and aspects of understanding (Hattie \& Timperley, 2007), thereby also promoting the informed evaluation of the student itself in order to achieve better learning achievements in the long term.

By studying the nature of feedback, the authors of the article raise questions about the types of feedback and how feedback interacts with the teaching and learning process. Feedback allows students not only to understand how they have performed the task and explain the assessment they have obtained, but also to provide guidance on how to improve their abilities, i.e., students learn to monitor, 
manage and take responsibility for their training (Nichol, 2007). In addition, it should be noted that feedback should be accurate and reasonable, not just correction of errors, marking or grading or one-word comment (e.g. "looking promising”) or writing negative equivalents (e.g. "not too keen”), or just editorial or grammatical corrections. Education researchers G. Gibbs and C. Simpson affirm that feedback can be used to „correct errors, develop understanding through explanations, generate more learning by suggesting further specific study tasks, promote the development of generic skills by focusing on evidence of the use of skills rather than on the content, promote meta-cognition by encouraging students' reflection and awareness of learning processes involved in the assignment and encourage students to continue studying” (Gibbs \& Simpson, 2004). Feedback may be either summarizing if it provides an explanation for marks or a format to help students to continue learning.

To sum up the theoretical literature analyzed above highlight that feedback is a targeted and premeditated critical learning process that is structured through the teacher to help students to learn and provide students with information that allows them to identify what kind of knowledge and skills they have acquired and what they need to learn through identifying future goals.

To provide feedback that students can understand and use productively is a certain challenge for all teachers. Jonsson uncovered five reasons why students may not engage with their feedback:

- $\quad$ it may not be useful,

- it may be insufficiently detailed or individualized,

- it may be too authoritative in tone,

- $\quad$ students may not know suitable implementation strategies,

- students may not understand the terminology used in feedback (Jonsson, 2013).

Effective and pedagogically based feedback is a contribution of the teacher to the learning process of students and has the positive impact on the results of the learning process. The new education content framework in Latvia (Skola2030) also emphasize the necessity for the effective feedback in the learning process. For example, international education expert G. Wiggins notes the most important feedback components. Feedback:

- „refers to the goal - effective feedback is possible if the performer has a goal, he takes action to achieve it and receives information on his actions towards achieving the goal;

- $\quad$ is visible and clear - any useful feedback system includes not only a reference to a clear goal, but also clearly visible results related to the goal;

- $\quad$ is actionable - effective feedback is concrete, specific and useful; it gives actionable information; 
- $\quad$ is user-friendly - even if feedback is specific and accurate in the eyes of experts, it is not helpful if the user does not understand it and takes it personally;

- $\quad$ is timely - feedback should not only be received from a teacher or even from people at all. Technology is one powerful tool - part of the power of computer-assisted learning is unlimited, timely feedback and opportunities to use it;

- $\quad$ is ongoing - our performance depends on not only receiving feedback but also having opportunities to use it;

- is consistent - performers can only adjust their performance successfully if the information fed back to them is stable, accurate, and trustworthy, at the same time, teachers must have the same opinion on what work of good quality is” (Wiggins, 2017).

Effective feedback is the information on the progress of a student towards a learning goal to achieve a positive result, feedback should be:

- $\quad$ informative and supportive to promote a positive attitude towards learning;

- $\quad$ timely, allow to use feedback to inform about learning and work;

- frequently and specifically enough to help students learn and work (Boud \& Associates, 2010).

Providing effective feedback is complicated: the relation between form, timing, and effectiveness of feedback is complex and variable (Price, Handley, Millar, \& O'Donovan, 2010). In general, for feedback to be effective it is essential students have positive perceptions about teacher feedback. Van der Schaaf et al. have showed that students who have feedback conversations with their teacher perceive teacher feedback as more useful (Van der Schaaf, Baartman, Prins, Oosterbaan, \& Schaap, 2011). Education researchers J. Hattie, H. Timperley (2007) and P. Black, D. Wiliam (2009) have developed models that explain the effective use of feedback. Both approaches agree that feedback is aimed at achieving changes in the education of students, so that the understanding and performance of students are consistent with the specific learning goals. Both models are based on three similar basic elements to be addressed in the feedback process (Table 1).

Table 1 Comparison of the feedback models (Black \& Wiliam, 2009) (Hattie \& Timperley, 2007)

\begin{tabular}{|l|l|}
\hline \multicolumn{1}{|c|}{ Model of Hattie and Timperley } & \multicolumn{1}{c|}{ Model of Black and Wiliam } \\
\hline Where am I going? & Where the learner is going? \\
\hline How am I going? & Where the learner is right now? \\
\hline Where to next? & How to get there? \\
\hline
\end{tabular}


Both models offer a view that effective feedback processes produce two main results: (I) teachers use and adapt effective learning strategies to help students succeed in areas that need attention; (II) students are changing their learning activities in order to achieve learning goals more effectively.

P. Black, D. Wiliam in their set out five framework strategies for a formative assessment or feedback. They are:

- clarification, exchanging and understanding of learning goals and achievement criteria;

- $\quad$ activities as proof of the training process;

- $\quad$ provide feedback that leads the student forward;

- $\quad$ students as teaching tools for each other;

- $\quad$ students as the managers of their own learning process (Black \& Wiliam, 2009).

P. Black, D. Wiliam place emphasis on self-regulation of students, which also corresponds to feedback levels developed in the study „The Power of Feedback” (2007) by J. Hattie, H. Timperley (Table 2).

Table 2 Feedback levels and their impacts (Black \& Wiliam, 2009)

\begin{tabular}{|l|l|c|}
\hline \multicolumn{1}{|c|}{ Level } & \multicolumn{1}{|c|}{ Description } & Impact \\
\hline Task & How well the tasks are understood and executed & Useful \\
\hline Process & $\begin{array}{l}\text { The main process required for understanding/fulfilling } \\
\text { tasks }\end{array}$ & Powerful \\
\hline Self-regulation & Self-monitoring, management and regulating activities & Powerful \\
\hline Self-level & $\begin{array}{l}\text { Personal assessment and impact (usually positive) on the } \\
\text { student }\end{array}$ & Ineffective \\
\hline
\end{tabular}

To sum up the previously analysed education researchers' J. Hattie \& H. Timperley (2007) and P. Black \& D. Wiliam (2009) models, it can be concluded that effective feedback consists of:

- a goal - feedback should be identified and it has to help to continuously advance the understanding of the student or the ability to carry out the task towards the learning goal;

- a focus - feedback should answer one or more of these questions to the student (and teacher): Where do I go? How do I go? Where to next?;

- a level - feedback can be provided in one or more of the four levels:

- the training activity - how well the task is understood or performed;

- $\quad$ the learning process - what the student should do to perform the task;

- $\quad$ self-directed learning - planning and self-monitoring; 
- $\quad$ the student as an individual person - personal characteristics of student;

- $\quad$ a result - the changes made as a result of feedback could be:

- bigger student activity;

- $\quad$ using of strategies more effectively;

- $\quad$ improving the autonomy, self-assessment and self-management of students;

- $\quad$ to provide more appropriate and specific goals;

- $\quad$ teachers adapt teaching strategies to meet students' needs.

Although students are primarily targeted to get a mark, there are a number of strategies that can be used to maximise students' involvement in the process, including providing effective feedback. The education researcher, D. Nicol, recommends splitting the tasks between stages and providing feedback, which is essential for the success of future phases. In addition, it is recommended that students should be asked to document how they have used feedback to move to the next phase of training. This strategy provides additional benefits through the development of students' metacognitive skills and a more active involvement of students in the process (Nicol, 2007). On the other hand, the researcher, M. Taras, recommends encouraging students to reflect on feedback comments and to give a preliminary assessment, while encouraging students to talk about their work and potentially earn higher marks. It is important to note that each teacher should listen to their students and accept the learning feedback (Murphy, 2000), thereby focusing on how students learn, receive feedback and analyse it (Phelps, 2000).

Student-focused feedback provides guidance on the learning process to the student, and the teacher pays attention to the decision, contribution and needs of the student. Teachers, using different tools, learning experience, help the student to improve performance. Learning experience is important as well as students motivating (Schmitt, Hu, \& Bachrach, 2008). A student-based approach means that the student is in the centre, thereby it is important to identify the previous knowledge, skills and attitudes of the student in the background of feedback, areas where the student has experienced difficulties, to carefully consider appropriate teaching activities, to advise and compare results, to set goals (Rowntree, 1994). Perhaps the problem is that students see feedback as isolated from other aspects of the teaching and learning process and believe that feedback is mainly needed by the teacher (Taras, 2003).

It can be concluded that by providing feedback to students, the lack of skills is analysed with a view to improving these skills, a constructive approach to learning is aimed at achieving awareness. Cooperation with the involvement of students and students in feedback is essential. When students receive feedback, the first step in the feedback process consists of perceiving the feedback, before 
even accepting or acting upon it (de Kleijn, Mainhard, Meijer, Brekelmans, \& Pilot, 2013).

\section{Clarification of students' views on the importance of feedback}

In order to clarify the opinion of students on feedback and the effectiveness of its application in the training process, a survey was conducted in one of Latvia's Secondary School in autumn 2019. There were 69 respondents in the survey, studying at the classes $6-8$.

The survey findings show that feedback to students is provided, but it does not provide full information on their achievements. Among girls dominate the view that teachers do not provide feedback that motivate them, while boys consider that providing feedback is not necessary.

41 respondent (59.42\%) wrote that their teachers did not give them a feedback which motivates, that is, teachers did not explain where and why students made mistakes, what to do to improve their performance, while 24 respondents (34.78\%) agreed that teachers have given them motivated feedback, but 4 respondents (5.8\%) did not answer the question.

Feedback comments should be detailed, constructive and motivating. This type of feedback contributes to learning, reduces misunderstandings and improves student achievements. Positive feedback should show the strengths of the student and motivate to improve achievements that are not good enough.

8 respondents (11.59\%) claimed that they had not received feedback from teachers in time and 12 respondents (17.39\%) had received feedback after a long time, while the majority of respondents -45 (65.22\%) received feedback timely, but 4 respondents (5.8\%) did not answer the question.

Timely feedback is effective feedback while delays in providing feedback reduce the chance for students to understand their mistakes and improve the performance (Hattie \& Timperley, 2007). Corrective feedback is essential in the learning process as it enables learners to understand whether their attempts to improve learning and experience have contributed to improvements (Hattie \& Timperley, 2007). The students indicated that in the most cases the feedback comments received were not taken into account because they did not give any indication on how to correct the errors. Teachers have given a mark but have not made comments that would justify why this mark in that case. It is clear from the above that students wait for informational and sufficient comments. If feedback comments are informative, they will help the students to understand their errors and how to correct them.

Respondents agreed that they are not given sufficient time or are not given the opportunity to provide feedback on tasks. During the lessons, teachers tend to "embrace the learning program" and mostly disregard feedback as a form of 
support strategy. Teachers who use effective feedback help students to objectively assess their abilities and teach them to use their strengths and to compensate disadvantages and promote internal motivation. Teachers should be encouraged to provide feedback on comments made by teachers. Students' feedback should be analysed in order to introduce the necessary changes and to improve feedback as a teaching and learning strategy. Feedback should always be provided in a time, as learning requires determined efforts, timely feedback will help the student acquire knowledge and skills.

\section{Conclusions}

1. Feedback is a targeted and premeditated critical learning process that is structured through the teacher to help students learn and provide students with information that allows them to identify what knowledge and skills they have acquired and what they need to learn by identifying future learning developments.

2. In recent years feedback has been talked about and written in the context of competency-based approach. As feedback effectiveness is variable, studies are needed on how to provide feedback to students. There are relatively less tools to assess the frequency, types and impact of feedback. There are a number of conditions required for feedback and which has a positive impact.

3. In order to make progress in the learning process, attention should be paid to what students learn, how they learn and how teachers impact this process, so that feedback plays a particular role in the learning process. The feedback process should include clear expectations for learning and performance of students, clarification on specific criteria for assessing students' achievements, performance-enhancing measures and a common understanding of "quality".

4. Feedback should become an integral part of the teaching process, teachers should encourage students to provide feedback on both their and teacher work. It would be advisable for teachers to analyse feedback results in order to improve the teaching and learning process.

5. The results of the survey show that students are willing to receive feedback, which would explain what has been achieved and help them to improve their performance, thereby reinforcing theoretical research on the meaning and effectiveness of feedback, by developing methodological recommendations for teachers in the multiplicity of feedback links in the learning process to encourage the growth of the teaching and learning process. 
SOCIETY. INTEGRATION. EDUCATION

Proceedings of the International Scientific Conference. Volume III, May $22^{\text {th }}-23^{\text {th }}, 2020.244-252$

\section{References}

Black, P., \& Wiliam. D. (2009). Developing the theory of formative assessment. Educational Assessment, Evaluation and Accountability, 21(1), 5-31.

Boud and Associates. (2010). Assessment 2020: Seven propositions for assessment reform in higher education. Sydney: Australian Learning and Teaching Council. Retrieved from https://ltr.edu.au/resources/Assessment\%202020_final.pdf

Boud, D., \& Molloy, E. (2013). Rethinking models of feedback for learning: the challenge of design. Assessment and evaluation in Higher Education, 38(6), 698 - 712.

de Kleijn, R.A.M., Mainhard, M.T., Meijer, P.C., Brekelmans, M., \& Pilot, A. (2013). Master's thesis projects: Student perceptions of supervisor feedback. Assessment and Evaluation in Higher Education, 38(8), 1012-1026.

Gibbs, G., \& Simpson, C. (2005). Conditions Under Which Assessment Supports Students' Learning. Learning and Teaching in Higher Education, 1, 3-31.

Hattie, J., \& Timperley, H. (2007). The Power of Feedback. Review of Educational Research. 77(1), 81-112.

Jonsson, A. (2013). Facilitating productive use of feedback in higher education. Active Learning in Higher Education, 14, 63-76. doi:10.1177/ 1469787412467125

Kluger, A., \& DeNisi, A. (1996). The effects of feedback interventions on performance: A historical review, a meta-analysis, and a preliminary feedback intervention theory. Psychological Bulletin, 119(2) 254-284.

Murphy, S. (2000). A sociocultural perspective on teacher response: Is there a student in the room? Assessing Writing, 7(1), 79-90.

Nicol, D., \& Draper, S. (2008). Redesigning written feedback to students when class sizes are large. Paper presented at the Improving University Teachers Conference, 29 July, Glasgow.

Nicol, D. (2007). Principles of good assessment and feedback: Theory and practice. Proceedings of the REAP International Online Conference on Assessment Design for Learner Responsibility.

Phelps, L. (2000). Cyrano's nose: Variations on the theme of response. Assessing Writing, 7(1), 91-110.

Price, M., Handley, K., Millar, J., \& O’Donovan, B. (2010). Feedback: All that effort, but what is the effect? Assessment \& Evaluation in Higher Education, 35(3), 277-289.

Rowntree, D. (1994). Preparing Materials in Open, Distance and Flexible Learning: An Action Guide for Teachers and Trainers. London: Kogan Page.

Schmitt, M., Hu, C., \& Bachrach, S. (2008). Course Evaluation and Assessment: Examples of a Learner-Centered Approach. Gerontology \& Geriatrics Education, 29(3), 290-300.

Taras, M. (2003). To feedback or not to feedback in student self-assessment. Journal Assessment and Evaluation in Higher Education, 28(5), 549-565.

The European Council. (2000). Presidency conclusions. Lisbon European Council.

UNESCO. (2005). Towards knowledge societies. UNESCO Publishing. Retrieved from http://unesdoc.unesco.org/images/0014/001418/141843e.pdf

Van der Schaaf, M.F., Baartman, L.K.J., Prins, F.J., Oosterbaan, A., \& Schaap, H. (2011). Feedback dialogues that stimulate students' reflective thinking. Scandinavian Journal of Educational Research, 57(3), 227-245.

Wiggins, G. (2017). Septiñas efektīvas atgriezeniskās saites pazìmes. Pieejams https://www.skola2030.lv/lv/jaunumi/blogs/septinas-efektivas-atgriezeniskas-saitespazimes 